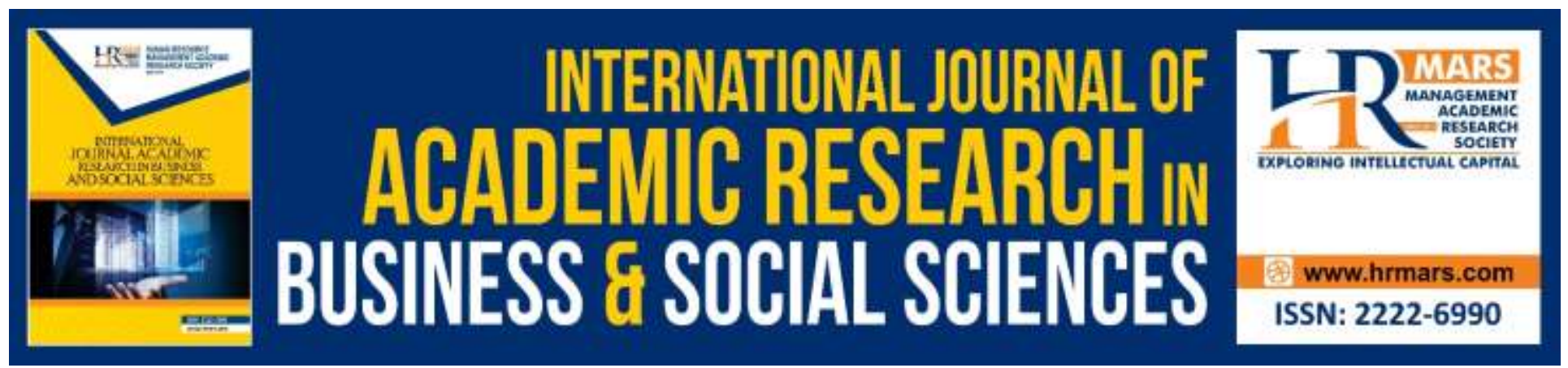

\title{
Validity and Reliability of Model Competency Instrument of Outdoor Education Co-Curriculum Center in Malaysia
}

Omar Firdaus Mohd Said, Md Amin Md Taff, Ahmad Hashim, Jaffry Zakaria, Mazuki Mohd Yasim, Mohd Shariman Shafie, Nik Jazwiri Johanis

To Link this Article: http://dx.doi.org/10.6007/IJARBSS/v10-i5/7170

DOI:10.6007/IJARBSS/v10-i5/7170

Received: 08 March 2020, Revised: 10 April 2020, Accepted: 27 March 2020

Published Online: 01 May 2020

In-Text Citation: (Said et al., 2020)

To Cite this Article: Said, O. F. M., Taff, M. A. M., Hashim, A., Zakaria, J., Yasim, M. M., Shafie, M. S., \& Johanis, N. J. (2020). Validity and Reliability of Model Competency Instrument of Outdoor Education Co-Curriculum Center in Malaysia. International Journal of Academic Research in Business and Social Science, 10(5), 33-49.

Copyright: (C) 2020 The Author(s)

Published by Human Resource Management Academic Research Society (www.hrmars.com)

This article is published under the Creative Commons Attribution (CC BY 4.0) license. Anyone may reproduce, distribute, translate and create derivative works of this article (for both commercial and non-commercial purposes), subject to full attribution to the original publication and authors. The full terms of this license may be seen at: http://creativecommons.org/licences/by/4.0/legalcode

Vol. 10, No. 5, 2020, Pg. $33-49$

http://hrmars.com/index.php/pages/detail/IJARBSS

JOURNAL HOMEPAGE

Full Terms \& Conditions of access and use can be found at http://hrmars.com/index.php/pages/detail/publication-ethics 


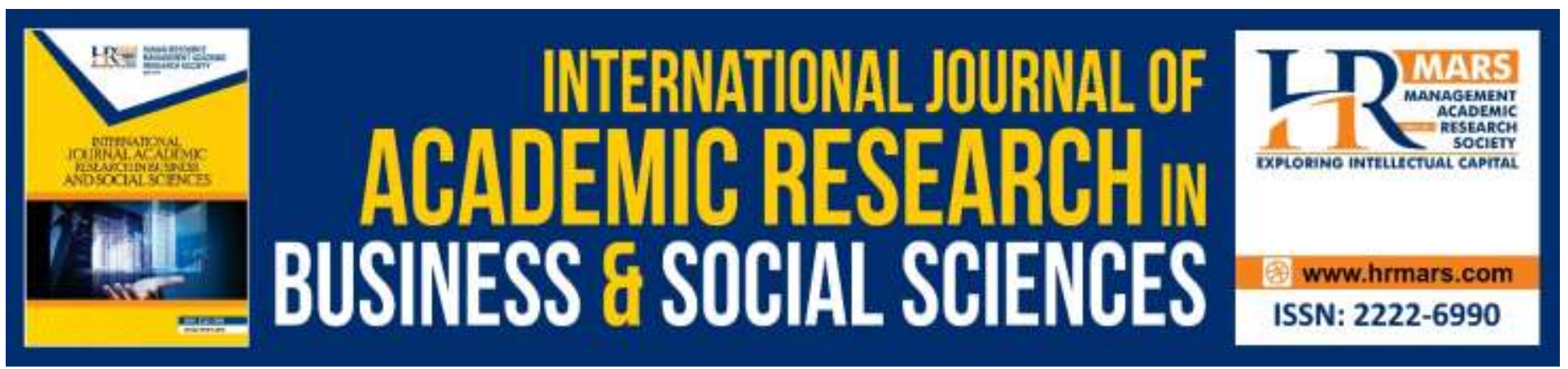

\title{
Validity and Reliability of Model Competency Instrument of Outdoor Education Co-Curriculum Center in Malaysia
}

\author{
Omar Firdaus Mohd Said ${ }^{1}$, Md Amin Md Taff ${ }^{2}$, Ahmad Hashim³ \\ Jaffry Zakaria ${ }^{4}$, Mazuki Mohd Yasim ${ }^{5}$, Mohd Shariman Shafie ${ }^{6}$, Nik \\ Jazwiri Johanis ${ }^{7}$ \\ 1,2,3,4,5,7Faculty of Sports Science and Coaching, Universiti Pendidikan Sultan Idris, Tg Malim, Perak, \\ Malaysia, ${ }^{6}$ Faculty of Sports Science and Recreation, UniversitiTeknologi Mara Kampus Seremban 3, \\ Negeri Sembilan, Malaysia \\ Email: omafir@gmail.com
}

\begin{abstract}
Recently, when competency issues takeover in Outdoor Malaysia landscape, it's been question among the outdoor practitioner and also outdoor organization in Malaysia how about the level of competency leaders in outdoor in Malaysia. In Malaysia, there is no tools in measures the competency level of outdoor leaders compare to the others develop country. In that case, it's invited the question how far the Malaysian Outdoor Leaders competency. Furthermore many accidents involved in Outdoor education and Outdoor recreation program affect the credibility of them. Meanwhile, this article is to explain the scenario and issues in develop the new assessment instrument of competency outdoor education leaders in Malaysia.
\end{abstract}

Keywords: Competency Leaders, Assessment Instrument and Outdoor Education and Outdoor Leaders, \& Co-Curriculum Center.

\section{Introduction}

The Ministry of Higher Education (2010) stated, teaching processes is a part of what is called as competency which includes personal, professional as well as social matters such as education, mastering a subject, theories related to education and studies, educational management, adapting to the community as well as personality. According to the matter above, it is hence related to one's ability to conduct a teaching process well and effectively. As time passes by, one's development continues to develop alongside with the growth of technology. Today, in a vast changing world, the ability to act flexibly requires high competency (Fullan, 2011). Fullan sees the need of competency as a one of the main necessities in completing a task. This shows how important it is for an individual to be competent in fulfilling a task. According to Seemiller and Murray (2013), competency is 
knowledge, value, ability (skills and motivation) as well as actions that contribute to the effectiveness of fulfilling a task. Competency hereby refers to an individual's ability to work on a task effectively.

Today, outdoor education is define as one of the educational medium platform in teaching and learning base on experience (experiental learning) that uses environment medium as an education lab. According to Hickman and Stokes (2016) they said, outdoor education isdefine as adventure education, education programming, learning outdoor education, environmental education, adventure therapy and experiental education.

Almost every year, the demand of outdoor activities are high. There are $53.1 \%$ was recorded on 2019 (Amin, 2020), about the involving community towards the outdoor education activities and outdoor recreation activities as a leisure time which can develop fitness, and also income profit. The high demand of outdoor activities directly gives a higher value to the outdoor education landscape in Malaysia. More agencies and company produces their outdoor coaches' expert base on their expertise. The high demand also involves universities and schools. In Universities, outdoor education were implemented in the course study and in co-curriculum activities (Amin, 2020)

In schools, outdoor education is entirely implemented by state or district co-curriculum center. The outdoor education activities were generated and manually conducted by state cocurriculum center. In others, there are also organized some outdoor activities by units and teachers at school (Omar, 2016).

\section{The Development of Outdoor Education in Malaysia's Co-Curriculum Center}

Pusat Kokurikulum (Co-Curricular Centre) is an Outdoor Education Organization established under the Bahagian Kesenian dan Kokurikulum (BKK) of Malaysia's Ministry of Education. BKK has two main focus which are to supervise and raise the artistic and curricular potential in Malaysia. One of the job scope and focus of BKK is the establishment of Co-Curricular in every Education Department State (JPN). Education Department State functions to ensure that all plans, activities, and practices of Outdoor Education is carried out in schools.

Co-Curricular Center is an organization established under the jurisdiction of Education Department State who acts as the planner and organizer of outdoor education programs designed specifically for school students in order to ensure the student's growth and identity development can be shaped to bring forth a generation of students according to Malaysia's educational philosophy (Md Amin, 2010). Furthermore, co-curricular also plays role in bringing forth outdoor education coaches who consist of teachers under Malaysia's Ministry of Education who are keen in conducting outdoor activities. There are about 14 state co-curricular center - district level - registered under Malaysia's Ministry of Education's Department of Co-curriculum \&Arts. Co-curriculum center at district level acts as the coordinator and organizer who plans out all outdoor education related programs for the students across the nation.

\section{Issues on Competency of Outdoor Education Coaches in Malaysia}

This research will bring forth a self - evaluating instrument on the competency of the outdoor education coaches in Malaysia. This research focuses on the evaluation of the competency of the coaches of outdoor education at co-curriculum center in Malaysia. The coaches of outdoor education at co-curriculum center is an organization named under Malaysia's Ministry of Education (KPM) as a group of coach responsible on the activities conducted on the students by outdoor education. These 
coaches are seen as a very important group in ensuring that all activities conducted by outdoor education is conducted well.

Based on the current development, high demands by the schools for outdoor education programme to be conducted is very welcoming. The schools sees these activities as such that can help in disciplining the students (Forgan \& Jones, 2002; Jaffry, 2008). Other than that, schools also see this program as one that can encourage the students to work harder and raise their academic achievements (Gass, 1987; Heyliger, 2002).The coaches of outdoor education at co-curriculum are individuals or groups that are responsible in ensuring that their abilities are of good qualities. Hence, to ensure that the coaches are of good quality, there is a need for an instrument that can be used to ensure their competency.

Until today, the standard competency of the coaches of outdoor education at co-curriculum is still debatable. This is due to the reason that there is not a single standard instrument that can be used to evaluate their level of competency. Hence, the standards of the coaches of outdoor education in Malaysia is still left behind in comparison to other countries in the world today. The absence of a unified standard to measure, gives privilege on the citizens to question their level of competency. How much further can these coaches go to encourage on their abilities in conducting outdoor education activities? There will always be a debate that arise on their competency in conducting outdoor education at co-curriculum. Standard competency level is hence very important as it is closely related to the quality of the coaches' experiences in conducting high risks activities. Preparing outdoor education coaches with good competency is meant to ensure that high risk activities can be conducted with zero risk of injuries or accidents.

In overall, instruments of a standard evaluation of the coaches' competency level should be implemented to ensure that there is a standard, quality and access to the scientific data of their competency. This shows that the coaches of outdoor education at co-curriculum center in Malaysia have their own standards and professional values. The development of this instrument enables the coaches to self - evaluate their competency. Other than that, it can also provide feedbacks to the organizer of co-curriculum center on the competence that need to further develop as well as allowing them to plan the types of level of activities that matches their level of competency.

\section{The Objectives of The Competencies of The Coaches of Outdoor Education}

The objectives of this research are to develop an instrument to evaluate the competency level of outdoor education coaches in co-curriculum center in Malaysia. Some of the objectives are:

1. To determine the content validity of the instrument of competency evaluation of the coaches of outdoor education co-curriculum State Zone in Malaysia.

2. To determine the construct validity of the instrument of competency evaluation of the coaches of outdoor education co-curriculum State Zone in Malaysia.

3. To determine the reliability of the instrument of competency evaluation of the coaches of outdoor education co-curriculum State Zone in Malaysia.

\section{Research Methodology}

To conduct this study the researcher chose to use quantitative Research method. In conducting this using quantitative method, the researcher uses the one-shot case study. 
INTERNATIONAL JOURNAL OF ACADEMIC RESEARCH IN BUSINESS AND SOCIAL SCIENCES

Vol. 10, No. 5, May, 2020, E-ISSN: 2222-6990 ㄷ 2020 HRMARS

\section{Research Questions on The Competency of Outdoor Education Coaches}

Based on the objectives of the research, this research aims at answering the questions below;

1. Is there any content validity in the instruments of the coaches of outdoor education cocurriculum State Zone in Malaysia?

2. Is there any construct validity in the instruments of the coaches of outdoor education cocurriculum State Zone in Malaysia?

3. Is there any reliability in the instruments of the coaches of outdoor education co-curriculum State Zone in Malaysia?

\section{Research Samples}

To conduct this research, the researcher use done group of sample which are sample (i) pilot study research sample. As for the pilot study, it is conducted on outdoor co-curriculum coaches in Kedah who will not take part in the real evaluation later on. Meanwhile, the area; research is conducted on a group of coaches in different chosen states across Malaysia. In choosing the sample, the researcher uses stratified sampling method.

\section{Research Design}

A research design in used by the researcher with the intention of ensuring that the research reaches its objectives. The researcher chose a mixed-mode research design which uses both qualitative and quantitative research design. This is due to the fact that the first phase of this research needs a qualitative measure. While the second phase of this research needs a quantitative measure as it focuses on the development of the new instrument. Hence, the process and implementation should focus more on the development of the instrument without observing the difference between the groups or etc. In terms of the instrument, the researcher is still developing a close-ended questions for the evaluation of the new competency value that is being developed. The benefit of developing a standardized close-ended question to the respondent is that it eases the analysis where codes can easily be analyzed by the computer (Morrow, Jackson, Disch, \& Mood, 2000). The researcher also chooses the 5-level grit scale adapted to test and evaluate each individual outdoor education cocurriculum center coach's level of knowledge, abilities and skills. There are five levels of scale set by the researcher, which are (i) Not at all like me, (ii) Not much like me (iii) Mostly like me, (iv) Like me, (v) Very much like me. Higher value of response shows high level of knowledge, ability and skill of an individual coach. Other than that, the researcher looks at this scale in a very wide perspective to evaluate one's opinion, reliability and attitude (Duckworth, 2016).

\section{The Phase of Research Implementation}

To explain the implementation of this research, the researcher has divided the implementation into three phases. The phases are the beginning phase (phase 1), the research implementation phase (phase 2) and feedback evaluation phase (phase 3).

\section{The Development of Instrumentation Items - Content Validity by a Panel of Experts}

In conducting the validation process, the researcher listed experts, consisting of 4 academic individuals, one national coach of Co-Curricular Center and one language experts who is known as the Main National Coach of Bahasa Malaysia (KSSM) for the year 2018. The experts appointed 
INTERNATIONAL JOURNAL OF ACADEMIC RESEARCH IN BUSINESS AND SOCIAL SCIENCES

Vol. 10, No. 5, May, 2020, E-ISSN: 2222-6990 @ 2020 HRMARS

evaluates all of the instruments mentioned. The experts will answer all of the instruments and look at its suitability according to the attributes and sub-attributes listen in the 'Brick Wall' model. By using 10-level scales, represented by 0 -10 (disagree to really agree), the experts will give a score on each of the items developed by the researcher.

Table 3.1 Score Values of The Experts' Score

\begin{tabular}{lllcccccccc}
\hline \multicolumn{10}{c}{ Grading scores of instrumentation items } \\
\hline 0 & 1 & 2 & 3 & 4 & 5 & 6 & 7 & 8 & 9 & 10 \\
Disagree & & & & & & & & & $\begin{array}{c}\text { Really } \\
\text { Agree }\end{array}$ \\
\hline
\end{tabular}

According to Chua (2006), and Parsian (2009), the most important element in developing instrumentation items is the clarity of the word choice and sentence structure so that it gives the most accurate definition and format to the instrument. After the instruments are checked by the experts to decide of the validity of the content, the researcher uses a formula suggested by SidekMohd Noah and Jamaludin Ahmad (2005) in determining the experts' validity. The formula below helps determining its validity.

Score Total $(\mathrm{X})$

................... $\times 100 \%=$ The Overall Content Validity Achievement

Maximum Score

Table 3.2 Values of Content Validity by Panels of Outdoor Education Experts

Attribute Foundation

\begin{tabular}{lcccc}
\hline Experts / score & Philosophy & History & Psychosocial & Score \\
\hline Expert 1 & 7 & 8 & 9 & .80 \\
Expert 2 & 7 & 7 & 7 & .70 \\
Expert 3 & 7 & 7 & 9 & .75 \\
Expert 4 & 7 & 7 & 8 & .73 \\
Expert 5 & 7 & 7 & 7 & .70 \\
& & Total Value of $r=$ & .73 \\
\hline
\end{tabular}

Attribute Hard Skills

\begin{tabular}{lcccc}
\hline Experts / score & Safety & Technical & Enviroment & Score \\
\hline Expert 1 & 8 & 8 & 9 & .83 \\
Expert 2 & 8 & 8 & 8 & .80 \\
Expert 3 & 6 & 7 & 8 & .70 \\
Expert 4 & 8 & 8 & 9 & .83 \\
Expert 5 & 9 & 9 & 9 & .90 \\
& & Total Value of $\mathbf{r}=$ & & .81 \\
\hline
\end{tabular}


INTERNATIONAL JOURNAL OF ACADEMIC RESEARCH IN BUSINESS AND SOCIAL SCIENCES Vol. 10, No. 5, May, 2020, E-ISSN: 2222-6990 ㄷ 2020 HRMARS

Attribute Soft Skills

\begin{tabular}{lcccc}
\hline Pakar / skor & Instruction & Organization & Facilitation & Skor \\
\hline Pakar 1 & 9 & 9 & 9 & .90 \\
Pakar 2 & 9 & 8 & 8 & .83 \\
Pakar 3 & 7 & 8 & 8 & .75 \\
Pakar 4 & 9 & 9 & 8 & .86 \\
Pakar 5 & 9 & 9 & 9 & .90 \\
& & Total Value of $r=$ & & .85 \\
\hline
\end{tabular}

Attribute Meta Skills

\begin{tabular}{lcccc}
\hline Pakar / skor & Leadership & Communication & Decision Making & Skor \\
\hline Pakar 1 & 9 & 8 & 9 & .86 \\
Pakar 2 & 9 & 9 & 9 & .90 \\
Pakar 3 & 7 & 10 & 9 & .86 \\
Pakar 4 & 9 & 9 & 10 & .93 \\
Pakar 5 & 9 & 9 & 9 & .90 \\
& & Total Value of $\mathbf{r}=$ & .89 \\
\hline
\end{tabular}

Table 3.3 Values of Content Validity by Panels of Bahasa Melayu Atribute Foundation

\begin{tabular}{lcccc}
\hline Pakar / skor & Philosophy & History & Psychosocial & Skor \\
\hline Pakar Bahasa & 7 & 8 & 9 & .80 \\
& & Total Value of $r=$ & .80 \\
\hline
\end{tabular}

Atribute Hard Skills

\begin{tabular}{lcccc}
\hline Pakar / skor & Safety & Technical & Enviroment & Skor \\
\hline Pakar Bahasa & 8 & 8 & 9 & .83 \\
& & Total Value of $r=$ & & .83 \\
\hline
\end{tabular}

Atribute Soft Skills

\begin{tabular}{lcccc}
\hline Pakar / skor & Instruction & Organization & Facilitation & Skor \\
\hline Pakar Bahasa & 9 & 8 & 9 & .86 \\
& & Total Value of $r=$ & & .86 \\
\hline
\end{tabular}

Atribute Meta Skills

\begin{tabular}{lcccc}
\hline Pakar / skor & Leadership & Communication & Decision Making & Skor \\
\hline Pakar Bahasa & 8 & 8 & 9 & .83 \\
& & Total Value of $\mathbf{r}=$ & .83 \\
\hline
\end{tabular}

\section{Developing and Building the Instrument (Reliability of the Instrument)}

Reliability refers to the consistency of the questionnaire items of the research conducted (Ahmad Hashim, 2014). In the research conducted, researcher will look at the reliability of the instrument developed by the researcher after it goes through content validation phase by field and 
language expert. To observe the reliability of the instrument of this very competency self-evaluation, Cronbach Alpha $(\alpha)$ is used to determine the consistency of the questionnaire items. According to Ahmad Hashim (2014), Cronbach Alpha ( $\alpha$ ) value that is accepted as reliable is $0.71-0.99$ (the best).In order to obtain reliability in the instrument, the researcher need to conduct a pilot study. Pilot study refers to the implementation of a research that is similar to the real research that is to be conducted in order to obtain its reliability value. In carrying out this pilot study, the researcher fixed the $n$ value as $n=110$, which is needed to implement factor analysis. Ahmad Hashim (2014), stated that in order to use factor analysis, sample size needed is $n=150$ samples. However, according to Ahmad Hashim (2014), sample value of $n=110$ is enough and acceptable for a pilot study of factor analysis. He also further explained that factor analysis is used in order to measure the validity of a research battery or measurement and evaluation of the instrument. Alpha Cronbach model is hence used to determine the reliability and consistency of the coefficient value of the items in a questionnaire (Ahmad Hashim, 2014). According to Pallant (2001) index value of alpha 0.60 or above is observed as good for instrument scale with more than 10 items.

The Implementation of Pilot Study in Determining the Reliability of Outdoor Education CoCurriculum State Zone in Malaysia's Level of Competency Evaluation.

In conducting the pilot study, the researcher posted out 110 sets of questionnaire to CoCurriculum Center in Kedah. The researcher also included permission documents from the Ministry of Education as well as Jabatan Pendidikan Negeri in order to carry out a research at Pusat Kokurikulum Negeri. The researcher was informed by Co-Curriculum Center in Kedah that a meeting will be held with all of of the coaches by March 2019. The meeting is conducted to synchronize and organize programs and intelligent test on the coaches that year. About $n=216$ coaches were formally registered through Department of Co-Curriculum \& Art, Ministry of Education (KPM, 2017).

Table 3.4 Reliability Value of the Main Attributes of Competency Level Self Evaluation Instrument of Coaches of Outdoor Education Co-Curriculum Center in Malaysia after Factor Analysis

\begin{tabular}{lr}
\hline Attribute & Alpha Value \\
\hline Foundations & .90 \\
Hard Skills & .88 \\
Soft Skills & .93 \\
Meta Skills & .92 \\
Overall Attribute & .91 \\
\hline
\end{tabular}

The measurement of statistics using coefficient Cronbach Alpha method is used to determine the reliability of consistency of the instruments of competency level self-evaluation instrument of Outdoor Education Co-Curricular Center State Zone in Malaysia. Table 3.4 shows the reliability of Cronbach Alpha for the main attributes consisted in the instrument of self-evaluation competency level. The result of the analysis shows that all main attributes in the instruments shows high values where attribute value for foundations ( $r=.0 .9)$, hard skills $(r=.88)$, soft skills $(r=.93)$ and meta skills $(r=.92)$. Therefore, in overall the main attribute consisted in the instrument of self-evaluation competency level of the coaches of Outdoor Education Co-Curiculum Center State Zone in Malaysia shows high consistency of reliability which is ( $r=.91)$. 
INTERNATIONAL JOURNAL OF ACADEMIC RESEARCH IN BUSINESS AND SOCIAL SCIENCES Vol. 10, No. 5, May, 2020, E-ISSN: 2222-6990 @ 2020 HRMARS

According to Pallant (2010), the process of factor analysis involves three main steps which are (i) evaluating data that are suitable for factor analysis,(ii) evocation factor as well as (iii) rotation factor and interpretation. In order to rate a certain data as good, the researcher need to ensure that the matrix value of reliability is at .6 corelation and above as its minimum value to be analyzed as good (Tabachnick\& Fidel, 2007). Meanwhile Barlett's Test of Sphericity and Kaiser - Meyer - Olkin (KMO) is used to observe if the sample used is suitable and is according to the terms. This factor analysis is suitable to be used when Barlett's test of Sphericity is at significant ( $p, 0.05)$ and KMO value of .50 or higher. Below are the validity construct of competency level self evaluation instrument of the coaches of outdoor education co-curriculum center in Malaysia.

Table 3.5 until Table 3.7 shows all of the instrumentation items that has gone through the factor analysis phases as well as reliability of instrument procedure. According to Ahmad Hashim (2015), factor analysis procedure is conducted to measure validity construct test battery or measurement and evaluation instrument. Apart from that, factor analysis is also used to identify items that has relationship with every components or variables related.

Table 3.5 : Finding Bartlett's Test and Kaiser-Meyer-Olkin (KMO) - Foundations

\begin{tabular}{|c|c|c|}
\hline Kaiser-Meyer-Olkin Measure & & .685 \\
\hline & & 2132.403 \\
\hline Bartlett's Test of Sphericity & $d f$ & 253 \\
\hline & Sig. & .000 \\
\hline
\end{tabular}

Table 3.6 : Finding Total Varian

\begin{tabular}{|c|c|c|c|c|c|c|}
\hline \multirow[t]{3}{*}{ Component } & \multicolumn{3}{|c|}{ Initial Eigenvalues } & \multicolumn{3}{|c|}{ Extraction Sums of Squared } \\
\hline & & $\%$ of & & & $\%$ of & \\
\hline & Total & Variance & Cumulative \% & Total & Variance & Cumulative \% \\
\hline 1 & 8.568 & 37.254 & 37.254 & 8.568 & 37.254 & 37.254 \\
\hline 2 & 3.045 & 13.238 & 50.492 & 3.045 & 13.238 & 50.492 \\
\hline 3 & 2.231 & 9.699 & 60.191 & 2.231 & 9.699 & 60.191 \\
\hline 4 & 1.402 & 6.096 & 66.287 & 1.402 & 6.096 & 66.287 \\
\hline 5 & 1.252 & 5.444 & 71.731 & 1.252 & 5.444 & 71.731 \\
\hline
\end{tabular}

Extraction Method: Principal Component Analysis. 
INTERNATIONAL JOURNAL OF ACADEMIC RESEARCH IN BUSINESS AND SOCIAL SCIENCES

Vol. 10, No. 5, May, 2020, E-ISSN: 2222-6990 @ 2020 HRMARS

\section{Table 3.7 : Construct Validity of Rotated Metrics}

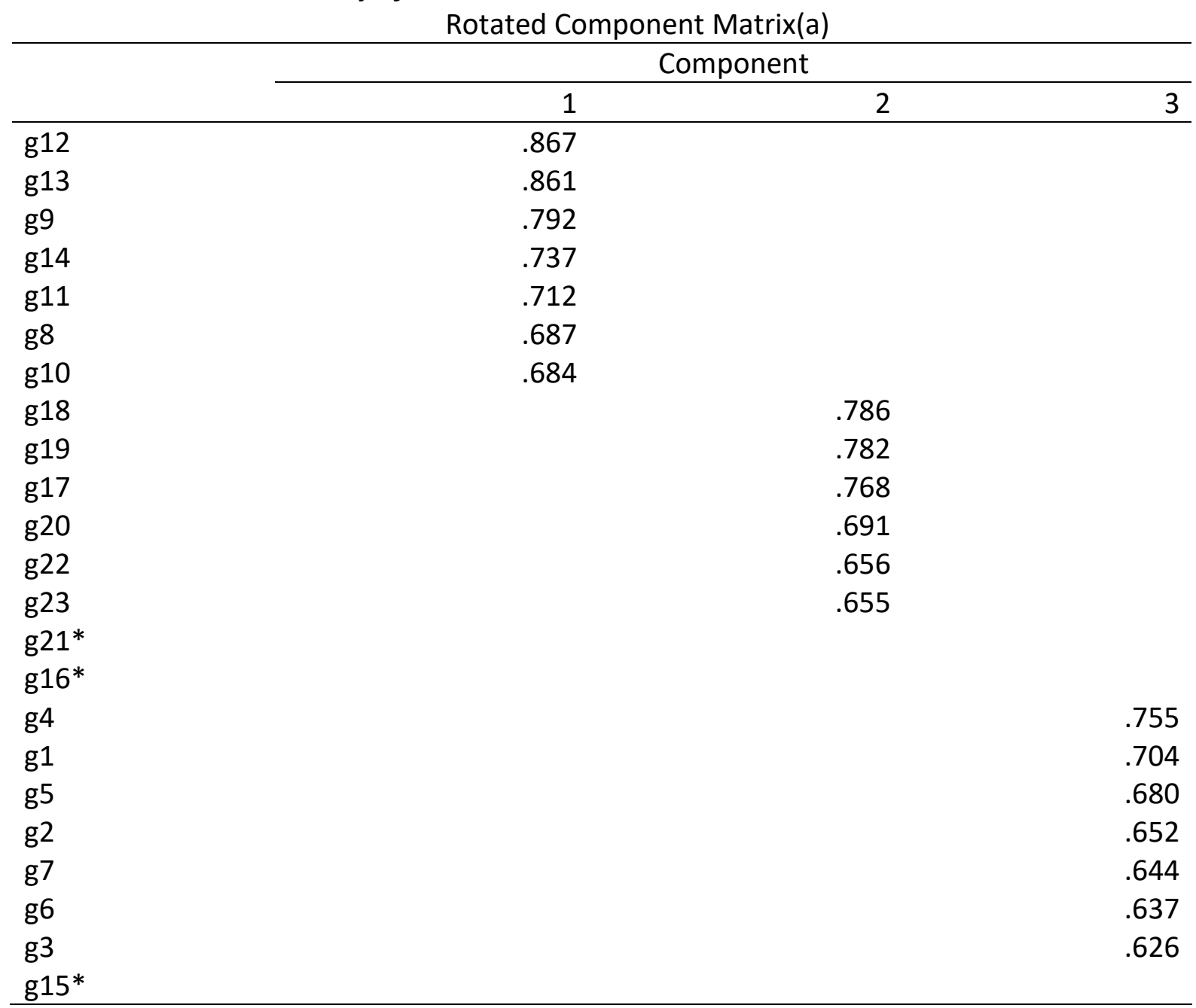

Extraction Method: Principal Component Analysis.

Rotation Method: Varimax with Kaiser Normalization.

a Rotation converged in 7 iterations.

Based on the factor analysis conducted, as for foundation attribute, seven items are seen as related to its sub attribute. The items consists of questions $8,9,10,11,12,13$ and 14 which represents sub attribute philosophy. Meanwhile, as for sub attribute history, items that represents history are item number $16,17,18,19,20,2122$ and 23 . There are a total of eight items that are related to history after going through factor analysis. As for the third sub attribute which is psychosocial, there are also eight items under this sub attribute which are numbered as 1,2,3,4,5,6, and 7 . Item 15 was delisted from the list.

About 3 out of 23 items in the questionnaire for attribute foundation was removed during factor analysis. This is due to the low value of loading factor which is lower than .60 which shows that there is no correlation between the item and the component or attribute. Hence, based on factor analysis conducted, only 20 items are accepted into the questionnaire for the foundation attribute, which consists of sub attribute such as philosophy, history and psychosocial. All of the items are reorganized according to its suitability of sub attribute as shown in the table below; 
INTERNATIONAL JOURNAL OF ACADEMIC RESEARCH IN BUSINESS AND SOCIAL SCIENCES

Vol. 10, No. 5, May, 2020, E-ISSN: 2222-6990 @ 2020 HRMARS

Table 3.8 : Finding Bartlett's Test \&Kaiser-Meyer-Olkin (KMO)-Hard Skills

\begin{tabular}{|c|c|c|}
\hline Kaiser-Meyer-Olkin Measure & & .719 \\
\hline \multicolumn{2}{|c|}{ Approx.Chi Square } & 1903.962 \\
\hline \multirow[t]{2}{*}{ Bartlett's Test of Sphericity } & df & 210 \\
\hline & Sig. & .000 \\
\hline
\end{tabular}

Table 3.9 : Finding Total Varians

\begin{tabular}{|c|c|c|c|c|c|c|}
\hline \multirow[t]{3}{*}{ Component } & \multicolumn{3}{|c|}{ Initial Eigenvalues } & \multicolumn{3}{|c|}{ Extraction Sums of Squared } \\
\hline & & $\%$ of & & & $\%$ of & \\
\hline & Total & Variance & Cumulative \% & Total & Variance & Cumulative \% \\
\hline 1 & 7.861 & 37.433 & 37.433 & 7.861 & 37.433 & 37.433 \\
\hline 2 & 2.425 & 11.546 & 48.979 & 2.425 & 11.546 & 48.979 \\
\hline 3 & 2.149 & 10.234 & 59.213 & 2.149 & 10.234 & 59.213 \\
\hline 4 & 1.433 & 6.822 & 66.035 & 1.433 & 6.822 & 66.035 \\
\hline 5 & 1.128 & 5.371 & 71.405 & 1.128 & 5.371 & 71.405 \\
\hline 6 & 1.010 & 4.809 & 76.214 & 1.010 & 4.809 & 76.214 \\
\hline
\end{tabular}

Extraction Method: Principal Component Analysis 
INTERNATIONAL JOURNAL OF ACADEMIC RESEARCH IN BUSINESS AND SOCIAL SCIENCES

Vol. 10, No. 5, May, 2020, E-ISSN: 2222-6990 @ 2020 HRMARS

\section{Table 3.10 : Construct Validity of Rotated Metrics}

\begin{tabular}{|c|c|c|c|}
\hline & \multicolumn{2}{|c|}{ Component } & \multirow[b]{2}{*}{3} \\
\hline & 1 & 2 & \\
\hline g38 & .844 & & \\
\hline g43 & .803 & & \\
\hline g39 & .794 & & \\
\hline g40 & .740 & & \\
\hline g42 & .718 & & \\
\hline g41 & .674 & & \\
\hline g31* & .505 & & \\
\hline g37* & -.482 & & \\
\hline g44* & .375 & & \\
\hline g25 & & .890 & \\
\hline g26 & & .823 & \\
\hline g27 & & .795 & \\
\hline g24 & & .699 & \\
\hline g28 & & .600 & \\
\hline g29* & & .557 & \\
\hline g34 & & & .784 \\
\hline g36 & & & .741 \\
\hline g35 & & & .732 \\
\hline g32 & & & .718 \\
\hline g33 & & & .600 \\
\hline g30* & & & .441 \\
\hline
\end{tabular}

Extraction Method: Principal Component Analysis.

Rotation Method: Varimax with Kaiser Normalization.

a Rotation converged in 7 iterations.

Based on factor analysis conducted, as for the attribute Hard Skills (safety), there are 9 items related to the sub attribute. The items are question $31,37,38,40,41,42,43$, and 44 which is seen to represent safety. Meanwhile, as for sub attribute technical, the items that represent it is question number $24,25,26,27,28$ and 29 . As for sub attribute technical, there are six items that are seen to have relation to it after factor analysis procedure. As for the third sub - attribute, which is the environment, there are six items that are seen to have relation to the sub attribute environment. The items are numbered as 30,32,33,34,35 and 36.

5 out of 21 questionnaire items for attribute hard skills are removed in the factor analysis process. This is because, value in the loading factor is lower than .60 value which shows no correlation between the items and the component or attribute. Hence, based on factor analysis on;y 16 items are chosen as valid to be included into the questionnaire for the attribute hard skills which consists of safety, technical and environment. All of the items are reorganized according to its sub attributes as a result of factor analysis, as shown in Table 3.25 below. 
INTERNATIONAL JOURNAL OF ACADEMIC RESEARCH IN BUSINESS AND SOCIAL SCIENCES Vol. 10, No. 5, May, 2020, E-ISSN: 2222-6990 @ 2020 HRMARS

Table 3.11 : Finding Bartlett's Test \& Kaiser-Meyer-Olkin (KMO) - Soft Skills

\begin{tabular}{llr}
\hline \multicolumn{2}{c}{ Kaiser-Meyer-Olkin Measure of Sampling Adequacy. } & .804 \\
\hline \multicolumn{2}{c}{ Approx.Chi Square } & df \\
Bartlett's Test of Sphericity & Sig. & 2178.327 \\
& & .000
\end{tabular}

Table 3.12 : Finding Total Varians

\begin{tabular}{|c|c|c|c|c|c|c|}
\hline \multirow[t]{3}{*}{ Component } & \multicolumn{3}{|c|}{ Initial Eigenvalues } & \multicolumn{2}{|c|}{ Extraction Sums of Squared } & of Squared \\
\hline & & $\begin{array}{c}\text { \% of } \\
\text { Varianc }\end{array}$ & & & $\%$ of & \\
\hline & Total & $\mathrm{e}$ & Cumulative \% & Total & Variance & Cumulative \% \\
\hline 1 & 10.262 & 48.866 & 48.866 & 10.262 & 48.866 & 48.866 \\
\hline 2 & 1.818 & 8.657 & 57.523 & 1.818 & 8.657 & 57.523 \\
\hline 3 & 1.654 & 7.874 & 65.397 & 1.654 & 7.874 & 65.397 \\
\hline 4 & 1.135 & 5.407 & 70.804 & 1.135 & 5.407 & 70.804 \\
\hline 5 & 1.038 & 4.944 & 75.747 & 1.038 & 4.944 & 75.747 \\
\hline
\end{tabular}

Extraction Method: Principal Component Analysis.

Table 3.13 : Construct Validity of Rotated Metrics

\begin{tabular}{|c|c|c|c|}
\hline \multicolumn{4}{|c|}{ Rotated Component Matrix(a) } \\
\hline & \multicolumn{2}{|c|}{ Component } & \multirow[b]{2}{*}{3} \\
\hline & 1 & 2 & \\
\hline g45 & .771 & & \\
\hline g48 & .769 & & \\
\hline g46 & .763 & & \\
\hline g47 & .749 & & \\
\hline g50 & .748 & & \\
\hline g49 & .692 & & \\
\hline g54 & & .768 & \\
\hline g56 & & .762 & \\
\hline g53 & & .700 & \\
\hline g55 & & .693 & \\
\hline g59 & & .669 & \\
\hline g52 & & .648 & \\
\hline g57 & & .646 & \\
\hline \multicolumn{4}{|l|}{ g58* } \\
\hline \multicolumn{4}{|l|}{ g65* } \\
\hline g62 & & & .765 \\
\hline g64 & & & .762 \\
\hline g61 & & & .736 \\
\hline g63 & & & .614 \\
\hline g60 & & & .606 \\
\hline g51* & & & \\
\hline
\end{tabular}

Extraction Method: Principal Component Analysis. 
INTERNATIONAL JOURNAL OF ACADEMIC RESEARCH IN BUSINESS AND SOCIAL SCIENCES Vol. 10, No. 5, May, 2020, E-ISSN: 2222-6990 ㄷ 2020 HRMARS

Rotation Method: Varimax with Kaiser Normalization.

a Rotation converged in 7 iterations.

Based on Factor Analysis for Table 3.13, Soft Skills (Lesson_attributes, there are six items seens as related to the sub attributes. The items consisted of questions 45,46,47,48,49 and 50 which are seen as a representation of sub attribute lesson. Meanwhile, as for sub attribute organization, the items that represent the sub attribute are $52,53,54,55,56,57,59$ and 65 . As for this sub attribute there are nine items that are seen as relatable after going through factor analysis procedure. As of the third sub - attribute facilitator, there are five items that are seen as relatable. The items are numbered as $60,61,62,63$, and 64 .

3 out of 21 items for this attribute has been eliminated during the factor analysis process. This is because, the value in loading paper is low at .60 which does not show any correlation between the items and its component or attribute. hence, based on factor analysis, only 18 items are accepted as soft skills attributes which consists of sub attribute such as lesson, organization and facilitation. All of the items are reorganized based on the suitability of sub - attribute from factor analysis as shown in Table 3.30 below:

Table 3.14 : Finding Bartlett'sTest \&Kaiser-Meyer-Olkin (KMO) - Meta Skills

\begin{tabular}{lrr}
\hline Kaiser-Meyer-Olkin Measure of Sampling Adequacy. & .751 \\
\hline \multicolumn{2}{c}{ Approx.Chi Square } & \\
Bartlett's Test of Sphericity & df & 2579.374 \\
& Sig. & 210 \\
\end{tabular}

Table 3.15 : Finding Total Varian

\begin{tabular}{|c|c|c|c|c|c|c|}
\hline \multirow[t]{3}{*}{ Component } & \multicolumn{3}{|c|}{ Initial Eigenvalues } & Extraction Sums of Squared & $\begin{array}{r}\text { ction Sums } \\
\text { Loadin }\end{array}$ & of Squared \\
\hline & & $\begin{array}{c}\% \text { of } \\
\text { Varianc }\end{array}$ & & & $\%$ of & \\
\hline & Total & e & Cumulative \% & Total & Variance & Cumulative \% \\
\hline 1 & 10.511 & 50.050 & 50.050 & 10.511 & 50.050 & 50.050 \\
\hline 2 & 2.442 & 11.628 & 61.678 & 2.442 & 11.628 & 61.678 \\
\hline 3 & 1.568 & 7.467 & 69.144 & 1.568 & 7.467 & 69.144 \\
\hline 4 & 1.142 & 5.437 & 74.581 & 1.142 & 5.437 & 74.581 \\
\hline
\end{tabular}

Extraction Method: Principal Component Analysis. 
INTERNATIONAL JOURNAL OF ACADEMIC RESEARCH IN BUSINESS AND SOCIAL SCIENCES Vol. 10, No. 5, May, 2020, E-ISSN: 2222-6990 @ 2020 HRMARS

\section{Table 3.16 : Construct Validity of Rotated Metrics}

\begin{tabular}{|c|c|c|c|}
\hline \multicolumn{4}{|c|}{ Rotated Component Matrix(a) } \\
\hline & \multicolumn{2}{|c|}{ Component } & \multirow[b]{2}{*}{3} \\
\hline & 1 & 2 & \\
\hline g78 & .871 & & \\
\hline g69 & .842 & & \\
\hline g70 & .824 & & \\
\hline g67 & .824 & & \\
\hline g75 & .728 & & \\
\hline g74 & .718 & & \\
\hline g68 & .691 & & \\
\hline g66 & .689 & & \\
\hline g73 & .669 & & \\
\hline g71 & .662 & & \\
\hline g77 & .651 & & \\
\hline g76* & .593 & & \\
\hline g85 & & .909 & \\
\hline g84 & & .901 & \\
\hline g83 & & .846 & \\
\hline g82 & & .732 & \\
\hline g86 & & .720 & \\
\hline g81 & & .632 & \\
\hline g80 & & .624 & \\
\hline g79 & & & .827 \\
\hline g72 & & & .731 \\
\hline
\end{tabular}

Extraction Method: Principal Component Analysis.

Rotation Method: Varimax with Kaiser Normalization.

a Rotation converged in 7 iterations.

Meanwhile, as for factor analysis conducted on the fourth attribute which is Meta Skills (Leadership), there are 11 items related to the sub attribute. The items are numbered as question $66,67,69,70,71,73,74,75,77$ and 78 as they represent sub attribute leadership. Apart from that, items under sub attribute leadership also consist the most number of items in the instrumentation of competency level. Apart from that, sub attribute communication consist of questions number $80,81,82,83,84,85$ and 86 . There are seven number of items related to communication after going through factor analysis procedure. As for the third sub attribute, which is decision making, there are only 2 items, which are numbered as 72 and 79 respectively.

After all items have gone through factor analysis procedure, the researcher observes that out of 86 total items, 12 items have been eliminated from the list. Two of the items eliminated, which are item 15 and 51, are seen to have no relation to the sub attribute. While item 10 is rid off due to its loading factor not reaching the value of .60. Hence, the new self-evaluation of competency level instrument consists of only 74 items after going through factor analysis. 


\section{Conclusion \& Discussion}

Overall, the researcher thinks that with the existence of this new instrument, long unanswered questions and debates will now be solved. This instrument can also be used on all Outdoor Education or Outdoor Recreation related matters to ensure the competency of coaches of Outdoor Education in Malaysia. Apart from that, the researcher also hope that with this instrument, the evaluation of the competency level can indirectly help Outdoor Education to set a unified standard, especially in bringing forth Outdoor Education coaches with caliber.

Through this writing, it is also clearly explained that the instrument has been developed through a very complicated manner to ensure that it encompasses all evaluation aspects of coaches of Outdoor Education in Malaysia. The researcher also suggest a few issues on future researches to be conducted in seeing the use of this instrument that has been developed to be effective to coaches in Outdoor Education or Outdoor Recreation in Malaysia. Some of the suggestions are;

i. To observe how far the competency level of the coaches of 'Malaysian Future Leadership School' (MFLS) which are under the agenda of the Ministry of Youth and Sports Malaysia in creating future leaders.

ii. To evaluate the effectiveness of competency level among the coaches of Outdoor Education for Education College all across Malaysia

iii. To evaluate level of competency of coaches and group of facilitators in public and private universities in Malaysia that are involved with programs under Outdoor Education or Outdoor Recreation.

In conclusion, the researcher sees the presence of this instrument as a positive insight towards Malaysia's Outdoor Education to be as competent as those in other countries that are more advanced.

\section{References}

Amin, M. T. (2004).A residential outdoor education camp and environment attitudes:A study case. Unpublished Master Thesis, University of Otago, Otago, New Zealand.

Amin, M. T. (2010). Effects of a residential outdoor education camp on environmental knowledge and attitudes of first year undergraduate students from selected Malaysian universities. Universiti Putra Malaysia., Malaysia.

Babbie, E. (2010) The practice of social research. 12th Edition, Wadsworth, Belmont.

Bahagian Kesenian \& Kokurikulum. (2017). Kementerian Pendidikan Malaysia.

Bryman, A. \& Bell, E. (2007). Business research methods. Oxford University Press, USA.

Chua, Y. P. (2016). Book 2 - Mastering Research methods:Univariate and multivarieate tests, $2^{\text {nd }}$ edition. Shah Alam, Malaysia: McGraw-Hill Education.

Creswell, J. (2009). Research design: Qualitative, quantitative, and mixed methods approaches (3rd ed.). Thousand Oaks, CA: Sage.

Duckworth, A. (2016). Grit: The power of passion and perseverance. New York, NY, US: Scribner/Simon \& Schuster.

Forgan, J. W., \& Jones, C. D. (2002). How Experiential Adventure Activities Can Improve students' Social Skills. Teaching Exceptional Children, 34(3), 52 -58.

Gass, M. (1987). The Effects of a Wilderness Orientation Program on College Students. Journal of Experiential Education, 10(2), pp.30-33. 
INTERNATIONAL JOURNAL OF ACADEMIC RESEARCH IN BUSINESS AND SOCIAL SCIENCES

Vol. 10, No. 5, May, 2020, E-ISSN: 2222-6990 ㄷ 2020 HRMARS

Hamidah, M. (2017). Pembinaan Pengujian Instrumen dan Pengukuran Tahap Profesionalisme Guru Bimbingan dan Kaunseling Sekolah Rendah Diserartasi Tesis Phd, Universiti Pendidikan Sultan Idris, Perak Malaysia.

Hashim, A. (2014). Panduan analisis data secara efisien. Bandar BaruBangi: Dubook Press Sdn. Bhd.

Hashim, A. (2015). Pengujian, pengukuran dan penilaian Pendidikan Jasmani. Bandar Baru Bangi: Dubook Press Sdn. Bhd

Helmer, J. (1977). The Connection between Narcotics and Crime. Journal of Drug Issues, 7(4), 405418. https://doi.org/10.1177/002204267700700411

Hussin, Z. (2003). Buku teks guru prasekolah komponen Pendidikan Islam (Preschool Teacher's Textbook Islamic Education component). Kuala Lumpur: Sun Publication.

Hussin, Z., Siraj, S., Jamil, M. R. M., Noh, N. M., \& Sapar, A. A. (2016). Elemen Kerohanian Sebagai Asas Keusahawanan Berintegriti. Dlm Enhancing Social Entrepreneurship, Empowering Community. Kuala Lumpur: Institut Sosial Malaysia

Malaysia Education Blueprint (PPPM) (2013-2025). Putrajaya: Ministry of Education. http://www.moe.gov.my/cms/upload_files/articlefile/2013/articlefile_file_003108.pdf

Morrow, J. R., Jackson, A. W., Disch, J. G., \& Mood, D. P. (2000). Physical fitness and activity assessment in adults. Measurement and evaluation in human performance. Champaign IL: Human Kinetics, 222-71.

Pallant, J. (2004) SPSS survival manual: version 12, Open University Press

Pan, E., \& Heyliger, P. R. (2002). Free vibrations of simply supported and multilayered magnetoelectro-elastic plates. J. Sound and Vibration, 252 (2002), 429-442.

Sabitha, M., Mahmood, N. M., \& World Health Organization. (2009). Estimating the number of sex workers in Malaysia. Kuala Lumpur: Era Visi.

Seemiller, C. (2013). The student leadership competencies guidebook. San Francisco, CA: Jossey-Bass.

Sekaran, U. (2003) Research Methods for Business: A Skill-Building Approach. 4th Edition, John Wiley \& Sons, New York.

Shuib, A. S. (2009). Reka Bentuk Kurikulum M-Pembelajaran Sekolah Menengah. Unpublished Philosophy Doctorate Thesis: Universiti of Malaya.

Wiersma, W., \& Jurs, S. G. (2009). Research methods in education: An introduction. Boston: Pearson. Zakaria, J. (2008) "Paddle Sports", "The Encyclopedia of Malaysia : Sport And Recreation Isbn: 978 $9814155618 "$. 